\title{
NAS ASAS DO CAPITAL: EMBRAER, financeirização e implicações sobre os trabalhadores ${ }^{1}$
}

\author{
Lívia de Cássia Godoi Moraes*
}

\begin{abstract}
O objeto de análise deste artigo é o processo de crescente financeirização na empresa líder em aeronáutica no Brasil, a EMBRAER - Empresa Brasileira de Aeronáutica S.A, hoje, apenas EMBRAER S.A -, e os impactos sobre seus trabalhadores diretos e indiretos. A EMBRAER é a terceira maior produtora de avióes comerciais do mundo, cujo patamar de concorrência a faz primar por tendências organizacionais hegemônicas em âmbito mundial. A investigação, centrada em análise de conteúdo, a partir de documentos oficiais e pesquisas científicas até então publicadas, constatou quatro principais momentos de imbricação entre capital produtivo e capital fictício desde a sua privatização, em 1994, até o ano de 2012, quando se encerra a pesquisa: 1) a partir da década de 1990, quando a empresa foi privatizada; 2) de forma mais determinante, no início dos anos 2000, com a produção de aviões comerciais da família EMBRAER 170/190; 3) com a posterior pulverização de capitais, em 2006; e, por fim, 4) na mudança de razão social para fins de ampliação de áreas de atuação da empresa, em 2010. O contexto em que se dão tais mudanças é o de mundialização do capital e prevalência de acumulação fictícia de capital, com fortes impactos sobre intensificação do uso da força de trabalho.

PALAVRAS-CHAVE: Financeirização. Trabalho. EMBRAER. Reestruturação Produtiva. Exploração.
\end{abstract}

\section{INTRODUÇÃO}

Pretende-se apresentar as formas como se tem dado, na prática concreta, o processo de financeirização em uma empresa brasileira de elevada importância nacional, a EMBRAER $\mathrm{S} / \mathrm{A}$, ou seja, as mudanças organizacionais e tecnológicas que a acompanham, e, principalmente, como esse processo impacta os trabalhadores diretos e indiretos da empresa.

Desde a década de 1970, está em curso o que Mészáros (2010, p. 69-70) denomina crise estrutural do capital. As principais justificati-

\footnotetext{
* Universidade Federal do Espírito Santo. Departamento de Ciências Sociais. Programa de Pós-Graduação em Política Social.

Av. Fernando Ferrari, 514. Cep: 29075-910. Vitória - Espírito Santo - Brasil. Secretaria Unificada dos Programas de Pós-Graduação do CCJE - SUPG

Anexo I. liviamoraes@outlook.com

${ }^{1}$ Este artigo tem por intuito apresentar os resultados principais da tese de doutoramento da autora, cujo título é "Pulverização de capital e intensificação do trabalho: o caso da EMBRAER", defendida em 2013. Uma primeira versão deste artigo foi apresentada no XIV Encontro Nacional da Associação Brasileira de Estudos do Trabalho, realizado em Campinas, na UNICAMP, em setembro de 2015. O presente artigo conta com importantes contribuicões dos integrantes do "Grupo de Estudos sobre Dinheiro Mundial e Financeirização", sob a coordenação do Professor Doutor Paulo Nakatani.
}

vas desse filósofo húngaro para considerá-la uma crise estrutural são o seu caráter universal, seu alcance global, sua escala de tempo contínua - se não permanente -, e, por fim, seu modo rastejante de se desdobrar. Com isso, o estudioso afirma que não se trata de uma crise conjuntural ou local. Há uma grande dificuldade de o capital alcançar as taxas de lucro do período pós-Segunda Guerra Mundial.

Uma das tentativas mais presentes nessas últimas quatro décadas de resposta contratendencial à queda da taxa de lucro que se apresenta é o "investimento financeiro". Dessa forma, via especulação, o capital fictício ganha importância. A resposta via financeirização não se restringe às empresas. No âmbito da política, ou melhor, dos Estados em geral, ocorreu um processo de desregulamentação financeira - que não deixa de ser uma espécie de nova regulamentação.

O desenvolvimento de tecnologia informática aliada à internet dá respaldo à aceleração das trocas, compras e vendas entre empresas que estão, geograficamente, do lado oposto do planeta, em transações de segundos, senão imediatas. A comunicação e o transporte 
alcançaram um patamar ótimo para a livre mobilidade do capital.

Foi a partir da expressão mais aparente dessa crise, em 2008, na chamada crise financeira, que sentimos a necessidade de nos debruçarmos sobre essa temática a partir da particularidade de uma empresa nacional. Dito de outra maneira: resolvemos investigar a particularidade de uma empresa brasileira, disposta na periferia da divisão internacional do trabalho, diante de um movimento mais universal, de crise estrutural do capital e de financeirização como resposta contratendencial a essa crise.

A pesquisa se desenvolveu no âmbito do doutoramento da autora, entre os anos de 2008 e 2012, com a apresentação dos resultados e defesa de tese em 2013. ${ }^{2}$ A hipótese desenvolvida foi a de que o processo de financeirização estava fortemente imbricado ao processo produtivo, com consequentes impactos sobre o processo de trabalho e sobre a condição de trabalho na EMBRAER. Tal hipótese se confirmou com o processo de investigação alicerçado em análise documental de relatórios da empresa e de diversas outras publicações por ela fornecidas, além de documentos e pesquisas com resultados apresentados nos formatos de monografias, dissertações, teses, artigos científicos e livros, além de reportagens sobre a EMBRAER.

₹ Trata-se, portanto, de uma análise que une eleసे mentos quantitativos e qualitativos.

.ี financeirização ${ }^{3}$ para explicar que dinheiro não के gera dinheiro "assim como a pereira produz के peras”, parafraseando Karl Marx, significava os superar a aparência, assimilar o complexo con$\stackrel{\sim}{*}$ traditório das relações de produção e circulação

2 Doutoramento desenvolvido no Programa de Pós-gra-

$>$ duação em Sociologia do Instituto de Filosofia e Ciências

ธิ Humanas da Unicamp, sob a orientação do Prof. Dr. Jesus Ranieri. de dominância financeira, foi Braga (1985, apud PRADO,

2014). A nossa leitura, assim como nas publicações de Car-

canholo, Nakatani e Sabadini, é no sentido de uma domi-

nância financeira, em se analisando o processo global do

ciclo do capital, como particularidades de um processo uni-

versal. Como bem explica Prado (2014), dominância finan-

ceira não é sinônimo de absolutização da lógica financeira. do capitalismo, e entender que a autonomia da esfera financeira não é senão relativa.

Em nossa investigação, constatamos que quatro momentos se destacaram como saltos na relação entre financeirização, produção e trabalhadores, com algumas fortes implicações negativas sobre esses últimos, tais como terceirizações, desemprego e intensificação de trabalho. São eles: a) a privatização da empresa em 1994 e a produção de avióes ERJ-145; ${ }^{4}$ b) a oferta pública global de capitais e produção da família de aviões EMBRAER 170/190, ${ }^{5}$ a partir de 2000/2001; c) a reestruturação de capitais e a entrada da EMBRAER no Novo Mercado da Bolsa de Valores de São Paulo, em 2006; e d) a nova razão social da empresa, EMBRAER S/A, em 2010, e a diversificação de seu objeto social.

Na conformação do artigo, faremos a exposição em seis seções, além desta introdução. Na primeira seção, apresentaremos a EMBRAER em seu contexto histórico de construção. Em seguida, caracterizaremos os quatro momentos relatados acima, acompanhados de explanação sobre as mudanças organizacionais e tecnológicas e de que forma elas atingem os trabalhadores. E, por fim, avançaremos para as considerações finais do artigo.

\section{DUAS DÉCADAS DE TURBULÊN- CIA: do nascimento à privatização}

A EMBRAER S.A. é a única empresa aeronáutica fora dos países centrais a se posicionar entre as "líderes globais", ocupando a oitava posição entre as maiores fabricantes de aeronaves e a terceira maior fabricante de aviões comerciais do mundo, atrás apenas da estadunidense Boeing e da europeia Airbus. No ano de 2012, ao final da pesquisa, a empresa possuía 17.970 assalariados, US\$12,4 bilhões de pedidos firmes em carteira, $\mathrm{R} \$ 8.284 \mathrm{mi}$ lhões de receita líquida e $\mathrm{R} \$ 444$ milhões de

\footnotetext{
${ }^{4}$ A família de aviões do ERJ é constituída por aeronaves com 37 a 50 assentos.

${ }^{5}$ Jatos de 70 a 122 assentos.
} 
lucro líquido. Atuava em cinco continentes e detinha, no mercado, 723.665.044 ações ordinárias ${ }^{6}$ distribuídas entre a Bolsa de Valores de Nova York e a Bolsa de Valores de São Paulo. ${ }^{7}$ Trata-se, portanto, de uma empresa economicamente expressiva em âmbito internacional, embora pouco pesquisada por estudiosos da Sociologia do Trabalho no Brasil. ${ }^{8}$

A EMBRAER nasceu na década de 1970, quando o mercado ainda era bastante regulado, e garantiu sua existência através do Estado, que financiou a produção e comprou uma grande quantidade de aeronaves quando do seu surgimento. O fim do período militar no Brasil e as políticas de cunho neoliberal acarretaram em um período de crise na empresa no final da década de 1980 e início da década de 1990.

A EMBRAER foi criada sob o regime militar, ou seja, quando o governo brasileiro desenhava seu projeto contrarrevolucionário (Fernandes, 2005), caracterizado pelo uso da violência militar para impedir qualquer revolução democrática brasileira. ${ }^{9}$ Tal período ficou conhecido como "milagre econômico". Uma leitura aprofundada explicita que não há "milagre" algum no fato de que o crescimento econômico se assente no recrudescimento político sob a tutela do grande capital - burguesia nacional, burguesia estrangeira e capital estatal nas mãos dos militares -, cuja política central foi a do decrescimento salarial e da superexploração da classe trabalhadora da cidade e

${ }^{6}$ Ações ordinárias são aquelas que concedem direito de voto nas assembleias deliberativas da companhia.

${ }^{7}$ Atualizando os dados a partir do último relatório publicado: ao final de 2014, a EMBRAER tinha mais de $19 \mathrm{mil}$ assalariados, US\$ 20,9 bilhões de pedidos firmes em carteira, R\$ 14.936 milhões de receita líquida e R\$ $796 \mathrm{mi}-$ lhões de lucro líquido. Nesse período, a EMBRAER possuía 740.465.044 ações ordinárias distribuídas entre a Bolsa de Valores de Nova York e a Bolsa de Valores de São Paulo.

${ }^{8}$ Destacamos a tese de doutorado de Roberto Bernardes, que resultou no livro Embraer: elos entre Estado e mercado, em 2000, e a dissertação de mestrado de Zil Miranda, que culminou no livro $O$ voo da Embraer, em 2007, ambas da Sociologia da USP (Universidade de São Paulo).

${ }^{9}$ É importante destacar que pensamos esse período como ditadura civil-militar, dado que as burguesias têm importante participação nas decisôes políticas e econômicas naquele momento. A Comissão Nacional da Verdade apurou que houve colaboração de mais de 80 empresas na ditadura militar brasileira, conforme aponta reportagem de $E l$ País de 08 de setembro de 2014. do campo (IANNI, 1981).

O êxito da fundação da EMBRAER se deve, majoritariamente, aos grandes benefícios que a fração burguesa militar deteve com o período da ditadura, de modo a expandir o complexo industrial-militar. Por outro lado, a crise e o fim do período autocrático burguês trouxeram uma série de problemas para a empresa.

É importante ressaltar que a EMBRAER já nasceu como uma empresa de economia mista, em cuja estrutura societária a União deteria, no mínimo, 51\% do capital votante, os quais deveriam ficar sob o controle do governo por meio do Ministério da Aeronáutica. Portanto, o laço com as finanças aparece desde o início de sua constituição, na medida em que até $49 \%$ do capital conformavam papéis na forma de ações. ${ }^{10} \mathrm{Tal}$ especificidade não está descolada do contexto internacional, dada a crise estrutural do capital da década de 1970, a qual tem relação direta com o fato de que a queda tendencial da taxa de lucro fez com que muitos capitalistas reinvestissem seus lucros na esfera financeira relativamente à esfera produtiva. ${ }^{11}$

A crise da EMBRAER se agravou com a produção do CBA-123 Vector, uma aeronave que deveria ser produzida em parceria com a Fábrica Militar de Aviones (FMA), de Córdoba, na Argentina. Com intuito de financiamento rápido, a EMBRAER efetuou o lançamento de US\$ 85 milhões de debêntures ${ }^{12}$ (Sandroni, 2008, p. 121) conversíveis em ações, segundo dados do Tribunal de Contas da União (TRIBUNAL DE CONTAS DA UNIÃO, 1994, s. p.). Entretanto, do lado argentino, as obrigações

${ }^{10}$ Pessoas jurídicas poderiam investir anualmente até 1\% do imposto de renda devido em ações da empresa, sem direito a voto, e deduzi-lo do Imposto de Renda de Pessoa Jurídica. Essa foi uma forma de capitalizar a empresa mediante investimentos privados, por exemplo (Bernardes, 2000a, p. 161).

${ }^{11}$ Ver mais sobre a crise de 1970 em Chesnais (1996), Mandel (1990) e Mészáros (2009, 2010).

${ }^{12}$ Debênture é qualquer "título mobiliário que garante ao comprador uma renda fixa, ao contrário das ações, cuja renda é variável. O portador de uma debênture é um credor da empresa que a emitiu, ao contrário do acionista, que é um dos proprietários dela. As debêntures têm como garantia todo o patrimônio da empresa. Já as debêntures conversíveis são aquelas que podem ser convertidas em ações, segundo condições estabelecidas previamente". 
financeiras não foram cumpridas, dificultando o pagamento dos juros comprometidos com as ações negociadas no mercado financeiro.

Enquanto, nacionalmente, a eleição de Fernando Collor de Mello significou a introdução efetiva da agenda neoliberal, internacionalmente, uma nova crise no setor aeronáutico despontava com a ideia de terrorismo, desde que Saddam Hussein foi acusado de organizar a invasão militar do Iraque sobre o Kuwait em 1990.

Uma das práticas que acompanham o ideário neoliberal é a privatização, aliada ao discurso de que as empresas estatais são ineficazes. A crise interna à EMBRAER, conectada com o fato de que, por ser estatal, não poderia receber recursos do Banco Nacional de Desenvolvimento Econômico e Social (BNDES), ${ }^{13}$ redundou no impulso para sua privatização, ocorrida em 1994.

Desse modo, ratificamos que o tripé financeirização, reestruturação produtiva e ideologia neoliberal estão intimamente conectados ao objetivo de o capital reverter a queda tendencial da taxa de lucro $^{14}$ e de criar novas condições de exploração da força de trabalho.

Tendo apresentado um breve panorama histórico da EMBRAER desde a sua fundação até a privatização no início da década de noventa - como empresa aeronáutica instalada em país periférico e, portanto, tendo determinações - reais e concretas específicas dessa condição -, กे passamos, a partir de agora, a analisar o contexto pós-privatização, acentuando os quatro moธี่ mentos que elencamos como mais relevantes ले no avanço da financeirização na empresa e seus

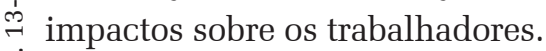

i $\quad$ Mas, antes de apresentar os resultados ¿ de nossa pesquisa, é preciso dizer que pensaiे mos a esfera financeira como relativamente

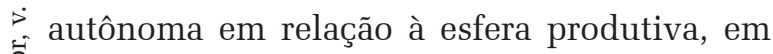
concordância com Nakatani e Sabadini:

${ }^{13}$ O BNDES injetou mais de US\$ 100 milhões, assim que a empresa foi privatizada (Fonseca, 2012), já que, antes disso, estava impedida, porque, por lei, esse banco não poderia financiar empresas públicas.

14 É preciso lembrar que a Embraer sozinha não reverte a queda tendencial da taxa de lucro, mas ela está inserida em um processo global de tentativa de responder a tal tendência.
A autonomia deve ser entendida como: "autônoma" porque atualmente a esfera financeira do capital tem a capacidade de se autogovernar, tem um grau de liberdade e de independência (como nos "lucros fictícios”) em relação ao capital produtivo e, também, em relação às instituições reguladoras, como os Bancos Centrais; mas, ao mesmo tempo, ela é "relativa”, pois absorve uma parte do valor gerado na produção, estando subordinada, assim, à esfera produtiva. Portanto, sua "independência” não é absoluta nem "descolada" totalmente do trabalho, o que torna o processo de desmaterialização do dinheiro ainda mais complexo (Nakatani; Sabadini, 2010, p. 78).

Essa imbricação entre reestruturação produtiva e reestruturação financeira, em nossa constatação, se apresenta de forma mais clara na EMBRAER em quatro momentos, sendo que, cada vez mais - o que parece ser uma tendência mais geral -, as reestruturações financeiras determinam fortemente as mudanças no âmbito produtivo. Não no sentido de uma via de mão única, mas com mútuas determinações. Entretanto, nas últimas décadas, segundo nossas investigações, o âmbito financeiro tem dado maior condução ao movimento de transformações na empresa.

Os quatro momentos que destacamos como mais relevantes são: 1) a partir de 1994, quando a empresa foi privatizada e com a construção da família de aviões ERJ-145; 2) de forma mais determinante, no início dos anos 2000, com a produção de aviões comerciais da família EMBRAER 170/190 e a venda de ações na Bolsa de Valores de Nova York; 3) com a posterior pulverização de capitais, em 2006 e entrada no Novo Mercado da Bolsa de Valores de São Paulo; e, por fim, 4) na mudança de razão social para fins de ampliação de áreas de atuação da empresa, em 2010. Vejamos mais de perto cada uma desses momentos.

\section{PRIVATIZAÇÃO E PRODUÇÃO DO ERJ-145: reestruturações e impactos sobre os trabalhadores}

Na década de 1990, o Brasil adentrou, 
de forma incisiva, no contexto da mundialização do capital. O processo de privatização das empresas estatais foi acelerado, conjuntamente com a desregulamentação do mercado de trabalho e a abertura financeira e comercial. Foi nesse contexto que a EMBRAER foi privatizada, e o mesmo processo de reforço das finanças e de enxugamento nas empresas para fins de resultados reais e financeiros que se observa no plano nacional e internacional, também se observa no interior dessa empresa.

A partir da privatização, houve uma transformação nos objetivos da EMBRAER: de excelência nos produtos para foco nos resultados, a partir de reestruturações financeiras e produtivas. Tal intuito ficou expresso nas palavras do novo presidente-diretor da empresa, Maurício Botelho: "[...] temos que olhar as finanças como instrumento do nosso desenvolvimento" (Drumond, 2008, p. 342). A implementação de tais mudanças tem relação direta com a produção de seu novo avião comercial, o ERJ-145.

Com a necessidade de responder aos interesses dos então acionistas controladores, houve intensa reestruturação produtiva na EMBRAER: cortes no quadro de funcionários; terceirizações; mudanças no layout da fábrica; aquisição de maquinário e novos softwares; mudança no perfil dos trabalhadores (mais jovens, mais qualificados, sem histórico sindical); gestão mais próxima do modelo toyotista; adoção de salário variável pautado em metas de produção; implantação de projetos de envolvimento subjetivo dos trabalhadores, tal como o projeto "Boa Ideia"; novos modelos de financiamento e fornecimento de peças, materiais e serviços a partir de parcerias de risco, fornecedores e subcontratados, dentre outros. A empresa também criou novas subsidiárias, especificamente para fins de financiamento das aeronaves, como é o caso da EMBRAER Finance Ltd. (EFL).

As transformações que envolveram o programa ERJ-145 se aproximaram muito do modelo toyotista de produção. O programa, iniciado antes da privatização, ganhou fôlego depois dela.

Entre os elementos principais do processo de recuperação da empresa, destacaram-se a reestruturação do endividamento, a captação de novos recursos e a conclusão do desenvolvimento do ERJ-145. Os novos controladores injetaram cerca de US $\$ 500$ milhões por meio da emissão de debêntures e obtiveram financiamento de US\$ 126 milhões com o BNDES. Esses recursos foram destinados, principalmente, ao desenvolvimento do ERJ-145 no período de 1995 a 1998 (Fonseca, 2012, p. 46).

Além da injeção de US\$ 500 milhões por parte de seus controladores (Bernardes, 2000a, p. 257), ${ }^{15}$ o projeto ERJ-145 foi pioneiro na indústria aeronáutica mundial ao realizar parcerias de risco (Martinez, 2007, p. 168-169). ${ }^{16}$ De imediato, foram terceirizados: restaurante, segurança, manutenção predial e execução de obras civis, manutenção de informática, despacho de importação, transporte, limpeza e setor gráfico (Malanga, 1997, p. 25). O piso salarial desses trabalhadores era nivelado com o piso dos trabalhadores da produção, algo que deixou de ocorrer a partir da terceirização (Bernardes, 2000a, p. 303), e essa foi a primeira das muitas diferenças que se seguiriam. A terceirização desses setores resultou em redução de custos de aproximadamente US\$ 80 milhões para a EMBRAER (Bernardes, 2000b, p. 25). Tal dado possibilita entrever as diferenças de salários e de condições de trabalho nas terceirizadas.

${ }^{15}$ Os controladores da EMBRAER a partir de sua privatização, passaram a ser: um consórcio de empresas formado pelo grupo Bozano Simonsen (40\%), pelo banco de investimentos norte-americano Wasserstein Perella (19,9\%) e pela CIEMB - Clube de Investimento dos Empregados da Embraer (10\%). Dentre os principais investidores do consórcio Bozano Simonsen estavam: o Bozano, Simonsen Limited, $(13,64 \%)$ o Sistel (Fundação Telebrás de Seguridade Social) $(10,42 \%)$, a Previ (Caixa de Previdência Privada do Banco do Brasil) (10,40\%), o Bozano Leasing $(3,63 \%)$ e a Fundação CESP (1,9\%).

${ }^{16} \mathrm{Na}$ modalidade de parceria, os riscos de sucesso ou de fracasso da aeronave são compartilhados com a EMBRAER. A empresa parceira é praticamente sócia da EMBRAER na aeronave específica do contrato, garantindo sua exclusividade no fornecimento de tal equipamento ou sistema. Existe uma espécie de "código de honra" não escrito de que as informações e projetos com as parceiras não serão repassados para as empresas rivais. Com a crise de 2008, tanto a Airbus quanto a Boeing resolveram adotar o sistema de parceria de risco, como ocorria com a EMBRAER desde sua privatização. Na produção do "Boeing 787", 90\% da produção passaram a ser terceirizadas (Barbosa, 2008). 
Dentre as transformações organizacionais para a retomada dos lucros da empresa estava um novo organograma, que passou a privilegiar o setor comercial, bem como modificações na área de comunicação, primordial para a introjeção dos "novos valores" na subjetividade dos trabalhadores.

Dentro do novo projeto organizacional também foi incluída a formação de lideranças e equipes de trabalho multifuncionais, sem atrelamento a cargos, com prazos e metas pré-determinados (Bernardes, 2000a). O trabalho em equipe foi incentivado, de modo que a vigilância tornou-se mútua. O caráter cooperativo do trabalho garantiu um avanço da capacidade produtiva para o capital, o que se acentuou com a divisão técnica do trabalho.

Outras modalidades de flexibilidade funcional foram implementadas no sentido de uma gestão mais integrada, o que eliminou desperdícios de materiais e de tempo, com busca de melhoria contínua (kaizen) de produtividade e "qualidade". Uma técnica adotada foi a de "trade studies", que consistiu na formação de grupos interdisciplinares que se reuniam para propor soluções no sentido de melhorias contínuas, e eram comumente utilizados em design aeroespacial e automotivo, e na seleção de softwares, buscando dirimir conflitos. Outro sistema adotado foi o "liason engineering", - que consistiu em um sistema de interligação ㄱ. entre as diversas áreas da empresa, auxiliando nas tomadas de decisões, na resolução de proธี่ blemas de times de trabalho, prestou suporte के ao produto na fase de montagem ou fabricação $\stackrel{\sim}{\rightarrow}$ etc. A adoção do "liason engineering" acarreके tou redução de $50 \%$ do ciclo de trabalho na $\stackrel{\sim}{a}$ fase de produção das aeronaves EMB-120 e iे ERJ-145 (Bernardes, 2000a, p. 295).

Houve também mudança no layout da empresa no sentido de redução de custo e de tempo de execução de tarefas. Uma delas foi a celurização, que consistia em colocar as máquinas ferramentas que produziam um conjunto de produtos similares no formato de células.

Todas essas transformações foram acom- panhadas de inserção de novas tecnologias, com softwares avançados, que pudessem colocar a EMBRAER em posição de competitividade com as maiores indústrias aeronáuticas do mundo.

A injeção imediata de capital pós-privatização quanto a inovações tecnológicas ocorreu desde os escritórios da empresa, com computadores novos, impressoras, fax, telefones celulares, notebooks, até no desenvolvimento e produção com o uso de CAD-CAM ${ }^{17}$ avançado e a instalação do software SAP ("Systems, Applications and Products in Data Processing”, ou "Sistemas, Aplicativos e Produtos em Processamento de Dados”), em 1996. Também foram instalados softwares que interligam parceiros e fornecedores entre eles, e com a EMBRAER.

A combinação de CAD-CAM, Engenharia Simultânea e mockup eletrônico, substituindo o mockup de madeira, ${ }^{18}$ possibilitaram uma redução de 50\% do pessoal alocado. Por exemplo, o número de engenheiros no projeto passou de 75 para 38 e houve uma economia de cerca de 93.000 homens/hora de trabalho e de aproximadamente US\$ 3 milhões (Bernardes, 2000a, p. 322).

Toda a reestruturação já feita imediatamente depois da privatização acarretou em novo corte de pessoal em 1995, quando 1.700 trabalhadores foram demitidos, sendo 1.200 do setor administrativo e 500 da área produtiva. A redução de engenheiros foi de $17 \%$ de um total de 700 (Bernardes, 2000a, p. 292). E, ainda, segundo estudo setorial do Departamento Intersindical de Estatística e Estudos Sócio-Econômicos - DIEESE (1998), a partir de 1995, os salários, que vinham em ascensão, passaram a cair.

Foram criados diversos projetos, reunidos no denominado Programa Transformação,

${ }^{17}$ CAD (Computer Aided Manufacturing - Produção Industrial com Auxílio de Computadores) e CAM (Computer Aided Manufacturing - Desenho com Auxílio de Computadores).

${ }^{18}$ Em princípio, era construído um protótipo de madeira (mockup convencional), a fim de eliminar problemas de desenvolvimento do avião, podendo voltar diversas vezes à fase anterior. Só depois de todos os problemas eliminados é que se passava à produção seriada. Hoje, é tudo feito de forma computadorizada. 
o qual tratava especialmente de ações da área de Comunicação, com o intuito próprio do toyotismo de "capturar" a subjetividade dos trabalhadores. ${ }^{19} \mathrm{O}$ principal projeto desse programa é o Boa Ideia. De 1995 a 1997, a EMBRAER teve uma economia de custos de US\$ 1 milhão (Bernardes, 2000a, p. 281). A base desse projeto é a filosofia kaizen, ou seja, melhoria contínua. Através dela, os trabalhadores foram motivados a disponibilizar seus conhecimentos tácitos e técnicos em prol da empresa.

O projeto Boa Ideia conseguiu, em 2006, alcançar uma redução de custo anual de US\$ 30 milhões. das metas estabelecidas no Plano de Ação e no Plano de Metas Setoriais (Martinez, 2007, p. 253). Ao que Oliveira (2002, p. 95) revela: “[...] a empresa espera ter seus empregados pensando e agindo como empresários. Quanto mais ele contribuir para o sucesso da empresa, mais ele obterá lucro e mais ele receberá parte desse lucro".

A remuneração variável, na forma de PLR (Participação nos Lucros e Resultados), era, nesse primeiro momento pós-privatização, equivalente a $25 \%$ dos dividendos e Juros sobre o Capital Próprio (JCP) creditados aos acionistas. Desse montante, 30\% eram distribuídos
Gráfico 1 - Projeto Boa Ideia. Redução de Custos (US\$ milhões)

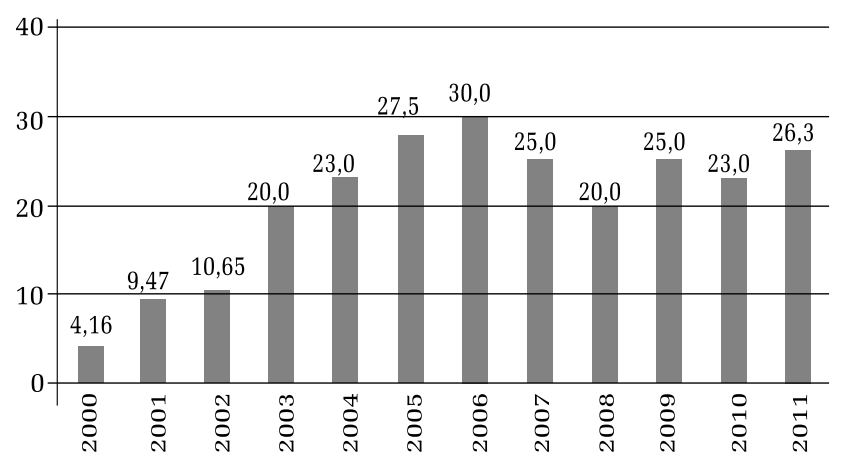

Fonte: EMBRAER, apud Moraes (2013)

A remuneração passou a ser pautada nas competências e habilidades desenvolvidas por seus funcionários. Ela passou a ser composta de duas partes: uma fixa e outra variável. A parte fixa é estabelecida a partir de comparação com o mercado local, de acordo com as qualificações. ${ }^{20}$ Já a parte variável é estabelecida em função dos resultados financeiros da empresa.

Dessa forma, com parte do salário sendo variável, foi possível estimular a produtividade a partir de maior envolvimento, comprometimento e melhor desempenho da força de trabalho. Para receber a parcela variável, o trabalhador precisava atingir o mínimo de $75 \%$

${ }^{19}$ Utilizamos "capturar" a subjetividade entre aspas porque, para nós, sempre há espaço para resistência: a captura nunca é completa.

${ }^{20}$ Tal parâmetro local faz com que o salário da EMBRAER esteja muito aquém do das demais indústrias aeronáuticas de destaque em âmbito internacional. em partes iguais a todos os empregados e 70\% de forma proporcional ao salário (EMBRAER, 2003).

Segundo Relatório Anual da EMRedução de custoBRAER de 2001, a (US\$ milhões) remuneração variável caracteriza "uma verdadeira parceria Acionista-Administração-Empregado". Ao que podemos constatar, essa parceria beneficia os dois primeiros em prejuízo do terceiro, que tem seu trabalho intensificado para cumprir as metas pré-determinadas, correndo o risco de não cumpri-las e não receber a parcela variável e, ainda, não ter esses valores incorporados no décimo terceiro salário ou na aposentadoria.

A EMBRAER ainda tem, por vantagem, estar em um país periférico e produzir um produto globalizado. Assim, os custos, principalmente os salários, estão muito abaixo dos de seus concorrentes. O valor do trabalho necessário é muito menor, pois os elementos que compõem o fundo de reserva dos trabalhadores são também menores. Dessa forma, o custo com capital variável, em cada unidade produzida, é diminuto e, aliado ao baixo grau de sindicalização e direitos frágeis dos trabalhadores (quanto mais dos terceirizados, quarteirizados 
etc.), possibilita a intensificação do trabalho com pouca resistência, o que acarreta aumento da cadência de produção sem contrapartida salarial. O gráfico a seguir ilustra o quanto a piora nas condições de trabalho significa melhora nos resultados para a empresa. Se, em 1991, a receita por empregado era de US\$33,7 mil, em 1998, já alcançava US\$ 254 mil, uma multiplicação de mais de sete vezes. Tal aumento retrata o nível de intensificação de trabalho pós-privatização.

Gráfico 2 - Receita por empregado (mil dólares) de 1991 a 1998

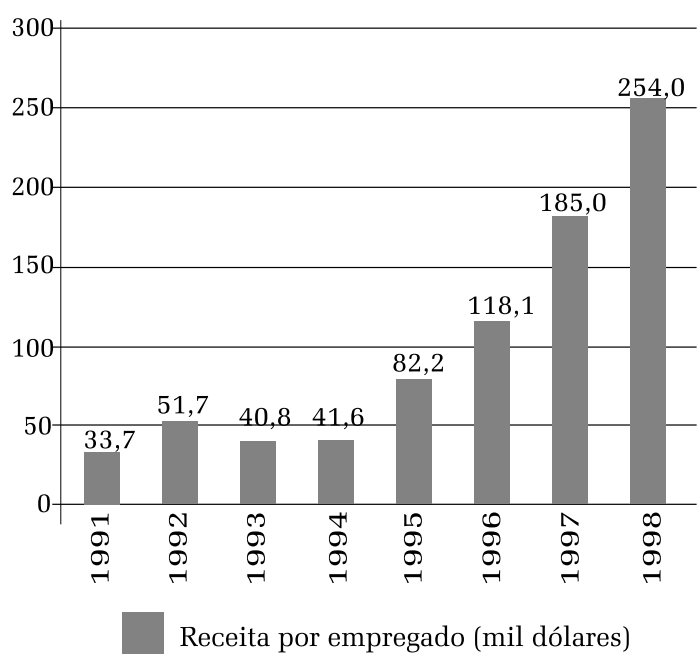

Fonte: EMBRAER, apud Bernardes (2000a, p. 298).

Conforme constatação de Godeiro (2009), a força de trabalho direta ${ }^{21}$ representa somente 8\% do total de custos da EMBRAER.

- Dentre as quatro maiores empresas de aviação comercial do mundo (Boeing, Airbus, EMBRAER e Bombardier), é a EMBRAER a que paga os salários mais baixos. "Enquanto o salário-hora do trabalhador da Boeing custa US $\$ 26,20$, o da Airbus US\$ 25,40 e o da Bombardier US\$ 20,48, o da EMBRAER custa apenas US\$ 8,10" (Godeiro, 2009, p. 46).

Estado foi intensa na EMBRAER pós-privatização, especialmente via BNDES. E não foi o caso somente da EMBRAER, conforme Fontes (2010, p. 316), pois o BNDES foi convertido em alavanca para a transnacionalização das empresas brasileiras.

${ }^{21}$ Excluem-se os trabalhadores terceirizados.
As reestruturações acima descritas conseguiram aumentar os lucros, reduzir os custos e, assim, valorizar as ações da empresa no mercado financeiro, bem como atrair parceiros de risco e instituições financeiras que financiassem produção e vendas das aeronaves. Tendo sido bem sucedidas, com projeção de enorme demanda por jatos regionais nos próximos 20 anos, a EMBRAER lançou uma nova família de jatos, a ERJ 170/190, posteriormente denominada EMBRAER 170/190.

\section{OFERTA PÚBLICA DE CA- PITAIS E A PRODUÇÃO DO MODELO EMBRAER 170/190: ações da EMBRAER alcançam a Bolsa de Nova York}

O crescente processo de financeirização no Brasil acarretou redução de gasto público com educação, saúde e seguridade social, com o objetivo explícito de obtenção de superávits primários. Ou seja, a necessidade de honrar com os compromissos financeiros - pagamento de juros sobre a dívida pública - se sobrepõe às necessidades sociais e programas de crescimento do setor real-concreto da economia. O pagamento de juros e as amortizações da dívida pública são considerados "intocáveis" pelo governo de cariz neoliberal (Ferreira, 2010, p. 52).

Sob essa lógica de acumulação financeira, inovações financeiras foram realizadas na EMBRAER, com o intuito de se obter mais liquidez para financiamento do novo programa, cuja projeção de custo de desenvolvimento era de US\$ 850 milhões (Bernardes, 2000a; Martinez, 2007). Entretanto, no relatório anual da EMBRAER de 2003, o orçamento para a família de jatos EMBRAER 170/190 já alcançava US\$ 1 bilhão.

Nos anos de 2000 e 2001, a EMBRAER lançou ações na bolsa de valores de São Paulo e na bolsa de valores de Nova York, com a 
oferta pública global de ações preferenciais ${ }^{22}$, o que possibilitou acesso a capitais mais baratos, de forma a levar mais acionistas norte-americanos e brasileiros ao risco empresarial (Silva, 2008, p. 225) e gerar recursos para investimentos referentes às reestruturações produtivas correspondentes ao programa das novas aeronaves da família EMBRAER 170/190. Conforme explica Martinez (2007, p. 273), a "EMBRAER esperou até 2000, quando já havia dado grandes passos na direção de sua inserção na economia global; abriu portas para consolidar o seu status de empresa global ao ofertar capital no mercado internacional”.

O Estado tem um papel muito relevante nesse sentido, de diminuir o "risco-Brasil" e tornar o mercado nacional de capitais atraente a financistas do mundo todo. Em 09 de novem- de Nova York e São Paulo, aumentando o freefloat $^{23}$ de 18,6\% para 47,4\%. O montante foi de US\$ 244 milhões (EMBRAER, 2000).

A segunda oferta global ocorreu em 2001 nas Bolsas de Valores de Nova York e de São Paulo, quando o BNDES lançou US\$ 300 milhões em títulos conversíveis lastreados em ADSs (American Depositary Shares), aumentando ainda mais o freefloat das ações preferenciais da EMBRAER, de 37,6\% para 59\% (EMBRAER, 2001). Os recursos captados nessas emissões foram destinados prioritariamente ao desenvolvimento das famílias de jatos EMBRAER 170/190.

As ações da EMBRAER já se encontravam listadas na Bolsa de Valores de São Paulo (BOVESPA) desde 1989. A partir da oferta global realizada em 2000, também passaram a bro de 1997, FHC revogou a Gráfico 3 - Primeira oferta global de ações preferenciais da Embraer. Julho de 2000 lei que limitava as ações de empresas nacionais a $40 \%$ nas mãos de pessoas físicas e jurídicas estrangeiras (Godeiro, 2009, p. 63), no intuito de atrair mais capitais para o mercado financeiro nacional e corroborar a força da burguesia internacional no Brasil. A EMBRAER, no âmbito mais particular, tem de Fonte: EMBRAER apud Moraes (2013). demonstrar ser uma empresa crescentemente lucrativa. Para tanto, requer constantes reestruturações produtivas que aumentem o patamar de extração de mais-valor do trabalho.

A primeira oferta global de ações preferenciais ocorreu em 21 de julho de 2000, quando a EMBRAER lançou ações simultaneamente nas Bolsas de Valores
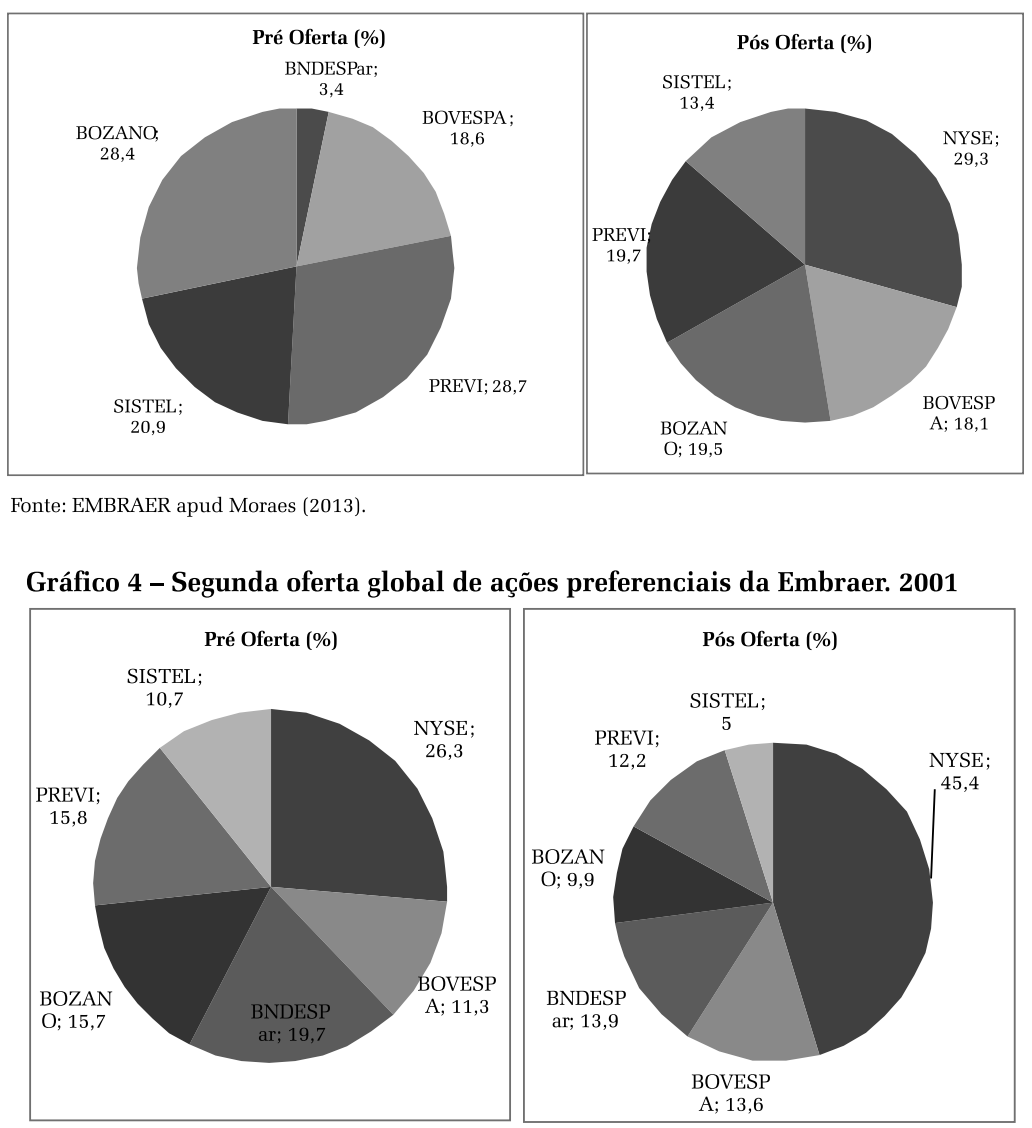

Fonte: EMBRAER, apud Moraes (2013).

${ }^{22}$ Ações preferenciais eram aquelas que ofereciam preferência na distribuição de resultados ou no reembolso do capital em caso de liquidação da companhia, não concedendo o direito de voto.
${ }^{23}$ Freefloat são ações que estão em circulação, ou seja, à disposição para negociação no mercado, excluindo-se as pertencentes aos controladores ou as que estão entesouradas pela companhia. 
constituir o programa ADR (American Depositary Receipts) Nível III, na Bolsa de Nova York. Além disso, a EMBRAER passou a integrar o índice Dow Jones Sustainability Index (DJSI). Para integrar esse índice, a empresa tem de ser considerada excelente em diversos itens, tais como: governança corporativa, código de ética, prevenção à "lavagem de dinheiro", controles internos, políticas de risco e crédito, condutas socioeconômicas e investimentos, entre outros (EMBRAER, 2000, 2001). O DJSI é referência para o universo de investidores financeiros, fazendo com que a EMBRAER se destaque no mercado de ações.

É interessante notar o quão mais proeminente a financeirização vai se tornando na EMBRAER, o que fica mais explícito nos seus relatórios anuais. Da privatização até o ano de 2001, seus relatórios anuais indicavam que o propósito fundamental da empresa era a "satisfação dos clientes”. No relatório de 2002, já aparece uma complementação: "Nessa satisfação, por sua vez, está a origem dos resultados da EMBRAER e da consequente geração de valor para seus acionistas". Algo que fica ainda mais patente no Relatório Anual de 2008, cuja geração de valor para o acionista passa a ser primordial:

O negócio da EMBRAER é gerar valor para seus acionistas através da plena satisfação de seus clientes do mercado aeronáutico global. Por geração de valor entende-se a maximização do valor da Empresa e ㄱ. a garantia de sua perpetuidade, com integridade de comportamento e consciência social e ambiental. relação, na maior parte das vezes, com a valorização no processo produtivo. Entretanto, somente o fato de ter existido uma oferta global ¿े já "melhorou a imagem da empresa", gerando $>$ uma valorização de $37,2 \%$ das ações ordinárias e $123,3 \%$ das suas ações preferenciais. As ADSs negociadas na Bolsa de Valores de Nova York em 21 de julho de 2000 apresentaram valorização de 115\%. Tal informação ilustra bem o que denominamos de valorização fictícia ou lucros fictícios, ou seja, lucros advindos da pura especulação, que não têm origem na extração de mais-valor, na exploração. ${ }^{24}$

A primeira peça do avião EMBRAER 170 foi usinada em julho de 2000. Destarte, essa valorização, apesar de também estar calcada nas projeções de vendas e de extração de mais-valor pelas reestruturações produtivas, respondeu velozmente a transações financeiras no mercado especulativo de ações.

Nos termos do Estatuto Social da EMBRAER, os acionistas titulares de ações de qualquer espécie têm direito a dividendos de, no mínimo, 25\% sobre o lucro líquido do exercício. Contudo, a satisfação das normas de rentabilidade acarretam degradação, controle e intensificação do uso da força de trabalho.

Uma estratégia de cooptação do capitalismo, sob a predominância financeira, é o stock option. O trabalho de envolvimento subjetivo não se dá apenas com os trabalhadores do chão de fábrica. Todos devem se adaptar ao léxico e às vontades das finanças, ou melhor, dos capitalistas que manejam o capital fictício a seu favor. Com isso, parte da remuneração dos dirigentes passa a depender do bom desempenho das ações das empresas em que trabalham. A EMBRAER, desde 1998, mantém um plano de opções de compra de ações, primeiramente para seus executivos, depois expandindo para empregados em geral e empregados de suas subsidiárias. Segundo relatório de 2002 da empresa, tratava-se de um "instrumento de motivação e retenção de profissionais".

As normas de governança corporativa aparecem para defender os direitos dos acionistas, dada a facilidade com que dirigentes manipularam resultados para se autobeneficiarem através de stock options. "Esse instrumento diabólico se voltou contra os acionistas, pois os dirigentes viram nisso um modo de satisfazer sua vontade de enriquecimento pessoal [...] Assim as stock options conduziram a desvios graves e explicam como hoje as remunerações dos dirigentes são frequentemente várias centenas de vezes superiores à dos assalariados" (Plihon, 2005, p. 145).

${ }^{24}$ Para se aprofundar mais detalhadamente sobre esse tema, ler Carcanholo e Sabadini (2015). 
O trabalhador, por um lado, fica preso aos resultados da empresa, dado que a valorização do capital produtivo reverbera nos preços das ações, e, com isso, intensifica tanto o próprio trabalho quanto dá sugestões de intensificação do trabalho alheio, de forma a contribuir para o aumento de taxa de exploração, e, assim, reduzir custos para aumentar os lucros da empresa. Por outro lado, fica vulnerável aos ditames do mercado e aos riscos que ele suscita. Não há garantia alguma de que, passados alguns anos, suas opções lhe gerem benefícios financeiros. Ademais, mesmo sendo proprietários de tais ações, esses trabalhadores não têm controle de como elas estão sendo manejadas.

Os resultados da oferta global de ações da EMBRAER puderam financiar a aquisição de novas tecnologias e mudanças organizacionais na empresa. O contato mais estreito com a empresa Dassault, através da aquisição de ações feitas por parte do Grupo Europeu, resultou na compra do software CATIA e na construção do Centro de Realidade Virtual (CRV). O software CATIA é muito mais poderoso que o $\mathrm{CAD}$, já que permite a realização do projeto em 3D (terceira dimensão), eliminando completamente a necessidade de protótipos (Bernardes, 2000a, p. 266). Esse equipamento informatizado reduz significativamente tempo e custo de produção. O tempo de desenvolvimento do EMB-120, com tecnologia analógica, foi de 64 meses; o do ERJ-145, com o uso do CAD, levou 54 meses para ser desenvolvido; já o do EMBRAER-170, com o CATIA, foi desenvolvido em apenas 38 meses (Yokota, 2004).

Houve uma nova e importante mudança no layout da empresa. Os aviões EMBRAER 170/190 passaram de montagem final em linha para montagem final em doca. Na montagem em linha, o avião era deslocado, enquanto os trabalhadores permaneciam fixos; já na montagem em doca, o produto se mantinha fixo, e as equipes de trabalho se revezavam, dependendo da fase do processo produtivo. Essa última requeria competências específicas dos trabalhadores, tais como polivalência e proativida- de, próprias da produção toyotista.

Todas as incorporações tecnológicas e mudanças organizacionais fizeram com que houvesse um salto na cadência produtiva de 3 aviões por mês, em 1997, para quase 18 aviões por mês, no primeiro semestre de 2001 (Godeiro, 2009, p. 44). A produtividade por empregado, no ano de 2000 , foi $24 \%$ superior à do ano anterior, segundo relatório anual daquele ano. Com isso, a EMBRAER dispensou 14\% do seu efetivo, cerca de 1800 trabalhadores.

A EMBRAER, no ano de 2005, devido aos avanços e ao expressivo destaque no mercado mundial de aeronaves, se preparava para o que o presidente da empresa à época, Maurício Botelho, considerou a mudança mais importante desde a privatização: a entrada no Novo Mercado da Bolsa de Valores de São Paulo através da pulverização de capital.

\section{PULVERIZAÇÃO DO CAPITAL, NOVO MERCADO E P3E: um salto na intensificação do trabalho}

Em 2006, a EMBRAER se tornou a primeira empresa brasileira de porte com capital totalmente pulverizado, passando a compor o Novo Mercado na Bolsa de Valores de São Paulo. Foi o mergulho definitivo da financeirização na empresa. A partir de então, a "adoção das melhores práticas de Governança Corporativa" passou a ser estratégica para o fortalecimento da relação entre acionistas e administração da empresa.

Plihon (2004) afirma que há, nos discursos aclamados da governança corporativa, dois objetivos principais: a) maximizar o valor das participações financeiras; e b) organizar um sistema de controle externo destinado a incitar os dirigentes das empresas a satisfazerem os objetivos dos acionistas. Os argumentos éticos ou de senso de justiça nada mais são que tentativas de "moralizar" as finanças modernas, alinhando as vontades dos acionistas a valores sociais, filosóficos, culturais e ecológicos. 
Os acionistas são incentivados, assim, a comprar ações de empresas que valorizam o meio ambiente e que não utilizam trabalho infantil ou trabalho escravo. São também orientados a votar nas Assembleias Gerais baseados em "valores éticos", de forma a influenciar os comportamentos dos dirigentes dos conselhos administrativos. Entretanto, Plihon (2004) alerta: ética e desempenho financeiro não são compatíveis.

Em 31 de março de 2006, em Assembleia Geral Extraordinária, foi aprovada a proposta de reestruturação societária da EMBRAER, apresentada em 19 de janeiro de 2006 pelo Conselho de Administração. O processo se deu da seguinte forma: a EMBRAER - Empresa Brasileira de Aeronáutica S. A. (a partir de então denominada "Antiga EMBRAER") foi incorporada por sua Controladora, Rio Han Empreendimentos e Participações S. A. A Controladora, que não possuía qualquer operação até a data da incorporação, passou a adotar a denominação social da EMBRAER - Empresa Brasileira de Aeronáutica S.A. ("Nova EMBRAER”). Desse modo, a “Antiga EMBRAER” foi extinta em 31 de março de 2006, e todos os seus acionistas receberam, em substituição às ações por eles detidas, novas ações de emissão da Companhia (EMBRAER, 2006).

A estrutura societária ficou assim disposta após a reestruturação de capital conforกิ me expressa o Gráfico 5.

\section{Gráfico 5 - Estrutura societária da Embraer (2006)}

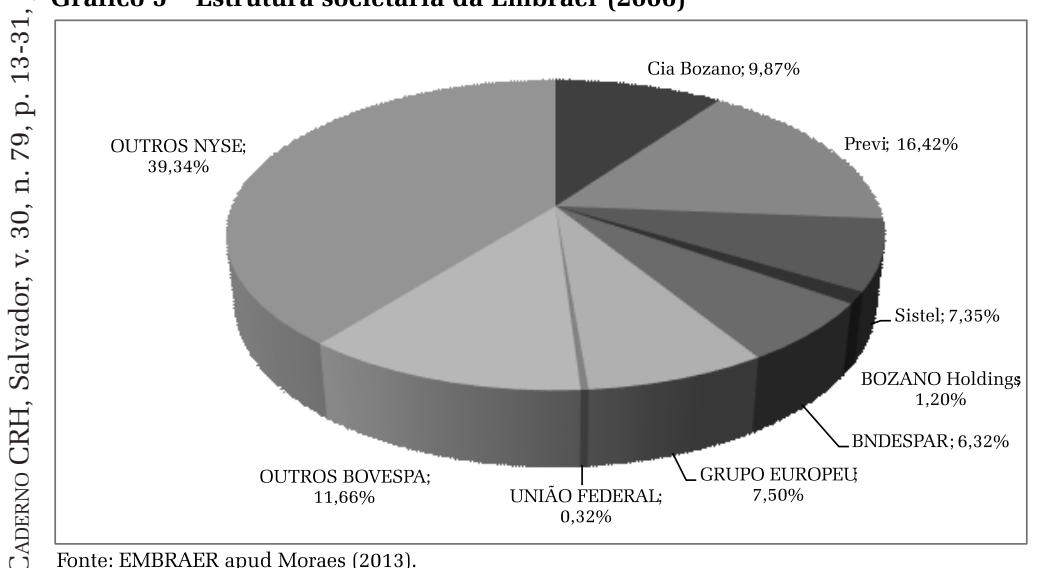

Fonte: EMBRAER apud Moraes (2013).
Podemos recorrer, aqui, à explicação de Carcanholo e Nakatani (1999), quando alertam para o fato de que o capital fictício tem suas raízes no capital portador de juros, embora ultrapasse os limites do que é necessário ao funcionamento normal do capital industrial. O capital portador de juros tem um papel importante para o capital industrial na medida em que o não proprietário do capital o utiliza como capital funcionante para produção de mais-valor. Já a autonomização sob a forma de capital fictício é perigosa, dado que exige um montante cada vez maior de mais-valor, embora pratique "atividade misteriosa" de produzir dinheiro sob a forma de especulação.

É importante destacar que não se trata de uma relação dicotômica entre capital fictício e capital real, mas sim de uma relação dialética. Um exemplo para explicitar tal relação diz respeito ao portador de uma ação da empresa cujo montante de ações de que dispõe ultrapassa seu patrimônio real. Para aquele portador do papel que representa uma quantidade de dinheiro, essa representação lhe é real, na medida em que até pode vendê-la para terceiros. Mas, na perspectiva da totalidade, não há uma completa correspondência em termos de riqueza real, ou seja, o capital é real e fictício ao mesmo tempo. Assim, em boa parte, as ações negociadas em bolsa de valores são pura especulação e geram lucros meramente fictícios.

Isso fica evidente quando a reestruturação societária da EMBRAER trocou papéis por outros papéis que certificam propriedade das mesmas ações, e isso a fez adentrar o Novo Mercado da Bovespa e obter a classificação de risco "Investment Grade" de duas das maiores e mais conceituadas agências de classificação de risco do mundo, a Moody's Investor Service e a Standard \&Poor's (EMBRAER, 2005). 
Tais classificações já resultaram em criação de "valor fictício" para os acionistas da EMBRAER. Ao final de 2006, a EMBRAER havia registrado valorização das suas ações de $22,5 \%$, cotadas em R\$22,05.

Não que haja um descolamento completo da base produtiva da empresa. Pelo contrário, aumenta-se ainda mais a pressão por extração de mais-valor. O elevado grau de exigência da governança corporativa e da globalização da empresa - agora não somente no âmbito produtivo, mas também acionário, com o aumento de vendas de ações a bancos e instituições financeiras estrangeiras - coincide com a contratação pela EMBRAER da consultoria Shingijutsu (Briales; Ferraz, 2006, p. 5), ${ }^{25}$ já anteriormente contratada pela Boeing e pela GE, com foco em Lean Production. Tal acordo acarretou diretamente em novas reestruturações produtivas dentro da empresa.

Na EMBRAER, essa consultoria resultou no Programa de Excelência Empresarial EMBRAER (P3E). O P3E endereçou suas ações, baseadas em Lean manufacturing, a todos os processos industriais: fabricação de peças e componentes, montagem estrutural e final, e até mesmo com relação a questões ambientais e comportamentais. Diante da sua aplicação no ano de 2007, já houve ganhos de produtividade e de ciclo de produção da ordem de $20 \%$. O objetivo era "descomplicar" a forma de trabalhar e eliminar desperdícios (EMBRAER, 2007).

Para internalização da filosofia Lean, a EMBRAER divulga, através de murais e documentos da empresa, "valores de modelagem de atitudes". Foram distribuídas cartilhas ilustradas e em linguagem acessível, denominadas "Guias de Consulta". De início, em uma delas, denominada "Projetos Kaizen e Melhoria Contínua: Guia de Consulta”, há a explicação do que seja o P3E: "Programa de Excelência Empresarial EMBRAER, que compreende uma

${ }^{25}$ A consultoria Shingijutsu formou-se através da associação de Taiichi Ohno, após a sua saída da Toyota, a alguns de seus "discípulos" mais aplicados. Essa associação resultou na criação de uma metodologia baseada em métodos e técnicas utilizados na Toyota. série de iniciativas em todas as áreas da Empresa”. Em seguida, explicam-se os objetivos do Programa:

Nossa causa: "Ser uma empresa de excelência na
qual clientes, acionistas e empregados se benefi-
ciem do que há de melhor em termos de práticas
empresariais e dos resultados decorrentes. Excelên-
cia, além de produtividade e lucro, significa satis-
fação, crescimento, realização e qualidade de vida
das pessoas, bem como assegura a perpetuidade da
Empresa" (EMBRAER, s. d., p. 5).

Por fim, apresenta o significado de Lean: "Lean é a base para a excelência, que nos mostra como fazer mais e melhor nossas atividades com o mínimo de recursos, mas sempre atentos ao cliente" (EMBRAER, s. d., p. 5). É exatamente nisso que se resume a filosofia Lean: $f a-$ zer mais com menos! Menos trabalhadores em alta intensidade de trabalho produzindo cada vez mais e mais rapidamente.

Não só a internalização dos valores e da conduta, mas também das metas e da filosofia lean seriam novas tarefas acumuladas pelos trabalhadores da EMBRAER. Eles deveriam, além de controlar a si, controlar o outro, seja no papel de liderança, seja na "avaliação $360^{\circ}$ ", seja no trabalho em equipe. Qualquer falha de conduta de outrem, que pudesse causar prejuízo à EMBRAER, a acionistas, parceiros, fornecedores e até outro trabalhador, poderia ser levada ao novo canal de denúncias da EMBRAER - o Canal de Práticas Danosas -, gerido por empresa terceirizada. Supervisionado diretamente pelo Conselho de Ética da empresa, o canal tinha por objetivo coibir desvios de materiais, corrupção, sabotagem, furto de pesquisa e know-how tecnológico, conforme é explicitado no Relatório Anual da Embraer de 2008, mas, principalmente, o que se observou, foi que ele corroborava o papel político de quebrar a solidariedade de classe e colocar os trabalhadores em concorrência.

Com a chamada crise financeira ou crise da bolha ${ }^{26}$, houve uma gigantesca desvaloriza${ }^{26}$ Tal crise financeira é compreendida como aparência de um processo que tem, na sua essência, a crise estrutural 
ção da empresa de 2007 para 2008. Seu valor de mercado passou de US\$ 8,4 bilhões, em 2007, para US $\$ 2,5$ bilhões, em 2008. As ações da Bovespa terminaram o ano de 2008 cotadas em R\$ 8,81, com desvalorização de 56\% com relação ao ano anterior. As ADS da Bolsa de Nova York atingiram US\$16,21, uma variação de -64,4\% em relação ao fim de 2007 (EMBRAER, 2008).

Aqui fica mais concreta a ideia de lucros fictícios apontada por Carcanholo e Sabadini (2015), quando os grandes lucros são frutos de especulação financeira e, "por mágica”, desaparecem como fumaça. Do ponto de vista individual, as ações existem efetivamente, ou seja, existe uma propriedade sobre elas. Mas, do ponto de vista da totalidade social, os lucros eram mera aparência, pois não advieram da exploração do trabalho, de modo que não tinham correspondência substancial. Isso fica mais claro quando objetivamente se observa aumento da taxa de exploração e, ao mesmo tempo, queda do valor de mercado da empresa em quase US\$ 6 bilhões.

Em fevereiro de 2009, 4.273 trabalhadoA res da EMBRAER foram demitidos. E, mesmo సे com a redução do quadro, um fator garantiu que o nível produtivo se mantivesse e até auฮี่ mentasse: o P3E. Um dos seus projetos consism tia na volta à montagem final para Linha, no $\stackrel{\text { m. }}{\rightarrow}$ lugar de Doca, quando há pressão do time de के trabalho da posição anterior sobre a posterior, $\therefore$ de modo que a montagem final baixou para 12 oे dias em 2009 e 8 dias em 2011 (EMBRAER, $>$ 2011). Destarte, verifica-se que as perdas são financeiras, mas as respostas a elas recaem firmemente sobre o âmbito produtivo.

Como é possível observar no gráfico a seguir, a cotação de ações da Embraer atingiu o seu mais baixo índice em fevereiro de 2009, do capital. quando seu preço foi de $\mathrm{R} \$$ 6,59. Esse baixo preço está diretamente relacionado à turbulência financeira no mercado de ações. Conforme Godeiro (2009, p. 15), a Embraer dispunha de $\mathrm{R} \$ 3,3$ bilhões em caixa quando do advento da crise, o suficiente para pagar todos os seus funcionários por dois anos, período em que a empresa divulgou que duraria a crise no setor. Mesmo assim, a opção se deu pela demissão. 
monstra o gráfico, logo depois da demissão em massa, o preço das ações começou a crescer. Contudo, isso não se restringe a algo pontual, pois a tecnocracia financeira exige transformações e inovações constantes e, em 2010, mais uma mudança ocorre: a mudança da razão social da empresa, dada sua atuação em novos nichos de mercado.

EMBRAER S.A.: nova razão social e impulsão de fusões e aquisições

Conforme se desenvolve o mercado mundial, a competitividade cresce. Três novos concorrentes diretos despontam no cenário internacional: China, Japão e Rússia.

Em 19 de novembro de 2010, os acionistas da EMBRAER, reunidos em Assembleia Geral, aprovaram duas importantes alterações no Estatuto Social da empresa:

a) a razão social mudou de EMBRAER - Empresa Brasileira de Aeronáutica S.A. para EMBRAER S.A.; b) foi também ampliado o objeto social da EMBRAER, acrescentaram-se os sistemas de defesa e segurança e o de energia à área aeroespacial (EMBRAER, 2010, p. 7).

Assim, foram incluídas e adicionadas as seguintes atividades ao objeto social da EMBRAER:

a) Projetar, construir e comercializar equipamentos, materiais, sistemas, softwares, acessórios e componentes para as indústrias de defesa, de segurança, e de energia, bem como promover ou executar atividades técnicas vinculadas à respectiva produção e manutenção, mantendo os mais altos padrões de tecnologia e qualidade;

b) Executar outras atividades tecnológicas, industriais, comerciais e de serviços correlatos às indústrias de defesa, de segurança e de energia (EMBRAER, 2010, p. 104).

Foi preciso diversificar as áreas de atuação, em função do risco de se ver sucumbida pela concorrência. As inovações tecnológicas continuaram a avançar, inclusive com a introdução intensificada de robôs. Como a teoria do valor marxiana explica, o mais-valor se extrai a partir do capital variável, ou seja, da força de trabalho, mas são crescentes as dificuldades em se diminuir o tempo de trabalho abaixo do socialmente necessário e garantir um mais-valor extraordinário frente à concorrência mundial.

A forma do capital fictício é facilitadora de centralização e concentração de capital promovendo os processos de fusões e aquisições. Tais movimentos, em geral, reforçam os níveis de exploração do trabalho e aumentam a rentabilidade produtiva e financeira, na medida em que, geralmente, vêm acompanhados de reorganização do trabalho e terceirizações. Nesse movimento, o número de subsidiárias da EMBRAER se multiplicou enormemente na última década, incluindo diversas delas com funções de bancos, ou seja, criadas para facilitar a movimentação financeira da empresa, e outras inúmeras aquisições relacionadas às novas áreas de atuação. Assim, "a riqueza real, que deveria ser a base da riqueza financeira, passa a ser produzida segundo seus imperativos" (Paulani, 2011, p. 67).

A EMBRAER, além da pulverização de capital, também trabalha com derivativos, recompra de ações e compra de títulos emitidos pela União. A composição societária da EMBRAER, em março de 2012, contava com mais de 50\% de ações na Bolsa de Valores de Nova Gráfico 7 - Composição societária Embraer - principais acionistas (março/2012)

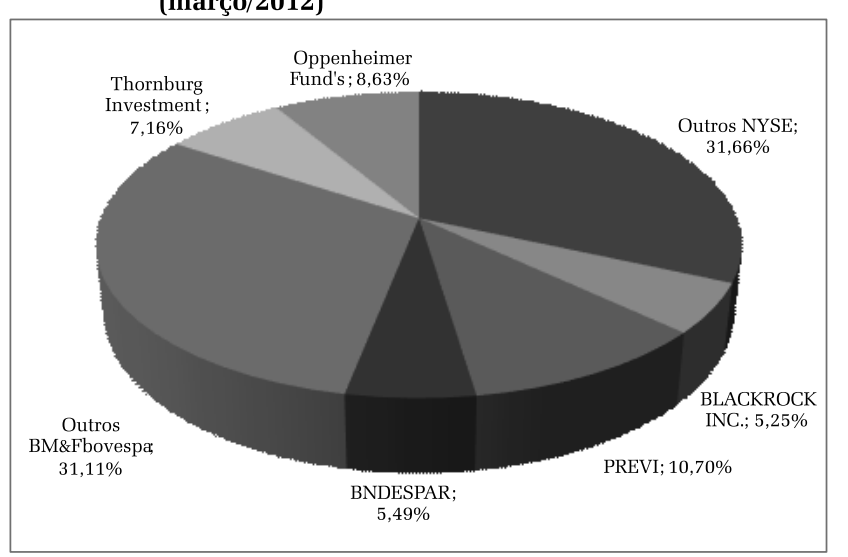

Fonte: EMBRAER apud Moraes (2013) 
York e mais de $20 \%$ de suas ações pertenciam a fundos financeiros norte-americanos.

Godeiro (2009, p. 86) alerta para o fato de que esse processo de financeirização da empresa faz com que ela corra o risco constante de se tornar mera subsidiária de outra grande empresa aeronáutica mundial, restringindo ainda mais as condições de resistência ao aviltamento das relações de trabalho.

\section{CONSIDERAÇÕES FINAIS}

Como foi possível observar através de nossa investigação, valorização produtiva e valorização fictícia estão fortemente imbricadas. Para haver valorização fictícia, é necessário que a empresa demonstre cotidianamente sua capacidade de produzir altas taxas de mais-valor, mesmo porque parte do que volta para as mãos de seus acionistas é mais-valor extraído via alto grau de exploração, com intensificação do uso da força de trabalho, enxugamento de quadros, rebaixamentos salariais, prolongamento não formalizado da jornada e terceirizações. Por outro lado, para produzir altas taxas de mais-valor, a empresa necessita cada vez mais do "crédito" advindo dos mercados de capitais.

Conforme fica evidente no Gráfico 5, a - cada avanço do processo de financeirização సิ na empresa, sempre conectado a mudanças organizacionais e tecnológicas, há valorização diี das ações no mercado financeiro. Apesar de o के gráfico ter seu ponto inicial apenas em 1999, $\stackrel{\text { m. }}{\rightarrow}$ podemos ver a curva crescente nas mudanças क de 2000 a 2001, com a oferta global de capi\& tais, ainda que uma crise do setor aeronáutico iे global tenha a afetado a EMBRAER em 2001, $>$ também em 2006, com a pulverização de capitais e entrada no Novo Mercado, e, em 2010, com a mudança da razão social da empresa e a diversificação de seu objeto social.

Classificada como primeiro momento de salto na perspectiva de financeirização, sua privatização, em 1994, foi marcada pelo "foco nos resultados", com intensa mudança organizacional, rumo a um modelo de gestão próximo ao toyotismo, com atenção à subjetividade dos trabalhadores, para a produção da família de aviões ERJ-145. Nesse sentido, não somente gestos velozes interessavam à empresa, mas também que esse trabalhador pensasse para a empresa. Isso fica bem patente no projeto Boa Ideia.

O segundo momento por nós elencado como mais relevante - a oferta pública de ações, a partir de então, também na Bolsa de Nova York - foi marcado por mais mudanças organizacionais, bem como inovações na tecnologia para produção das aeronaves da família EMBRAER 170/190, especialmente com softwares com projeção em 3D (terceira dimensão) e que conectavam operações da totalidade da empresa, acelerando o ritmo de trabalho e produção.

Um terceiro momento é o enorme salto na financeirização da empresa com a pulverização de capitais em 2006, quando todas as ações passaram a ser ordinárias, e a EMBRAER adentrou o Novo Mercado da Bolsa de Valores de São Paulo. Padrões de Governança Corporativa e Índices de Sustentabilidade passaram a controlar os rumos das mudanças organizacionais na empresa, o que determinou a instalação do P3E com metas de Lean Production (produção enxuta). Para os trabalhadores, houve intensificação do trabalho, padrões de autocontrole e de mútuo controle bastante altos.

Por último, dentro do período de investigação da pesquisa, como quarto momento, destacamos a mudança da razão social da empresa em 2010, o que a tornou apenas EMBRAER S. A., na medida em que a concorrência mundial impôs diversificação do objeto social da empresa, acompanhado de inúmeras fusões e aquisições e acentuado ritmo de trabalho, além da introdução de robôs na linha de montagem.

Em todos os quatro momentos houve demissões, terceirizações e intensificação do uso da força de trabalho, inclusive, das capa- 
cidades subjetivas dos trabalhadores, dentro e fora da jornada normal diária. O que se observa, portanto, é a predominância da forma fictícia sobre a forma real e produtiva, ainda que dentro de um movimento dialético entre ambas.

A EMBRAER avança no uso de instrumentos financeiros diversos: ações, títulos da dívida, papéis bancários, derivativos, fusões e aquisições via mercado de capitais, crédito sindicalizado via instituições financeiras, fundos de investimentos como principais acionistas etc. Ou seja, a empresa está vulnerável às vontades, desejos, oscilações, riscos e especulações financeiras, e, ao que se verificou, quem paga o preço mais alto por essas escolhas políticas e econômicas são seus trabalhadores.

Recebido para publicação em 31 de dezembro de 2015 Aceito em 24 de setembro de 2016

\section{REFERÊNCIAS}

BARBOSA, Mariana. Boeing e Airbus copiam Embraer para reduzir custos. Jornal Estadão. São Paulo, 23 abr. 2008.

BERNARDES, Roberto. EMBRAER: elos entre Estado e mercado. São Paulo: Hucitec, 2000a.

. Redes de inovação e cadeias produtivas globais: impactos da estratégia de competicão da Embraer no arranjo aeronáutico da Região de São José dos Campos. Rio de Janeiro: Instituto de Economia da Universidade Federal do Rio de Janeiro - IE/UFRJ, 2000b. ( Nota Técnica 23).

BORGES, Beatriz. Mais de 80 empresas colaboraram com a ditadura militar no Brasil. [S.l.]: El país, 08 set. 2014. Disponível em < http://brasil.elpais.com/brasil/2014/09/08/ politica/1410204895 124898.html>. Acesso em: 17 ago. 2015.

BRIALES, Júlio Aragon; FERRAZ, Fernando Toledo. Melhoria contínua através do Kaizen. Revista eletrônica de economia,[S.l], Ano IV, n. 7, março 2006. Disponível em: <http://www.viannajr.edu.br/site/menu/publicacoes/ revista_economia/artigos/edicao7/artigo_70002.pdf $>$ Acesso em: 25 set.2012.

CARCANHOLO, Reinaldo; NAKATANI, Paulo. O capital especulativo parasitário: uma precisão teórica sobre o capital financeiro, característico da globalização. In: Ensaios FEE, Porto Alegre, v. 20, n. 1, 1999.

CARCANHOLO, Reinaldo; SABADINI, Maurício. Capital fictício e lucros fictícios. In: GOMES, Helder. (Org). Especulação e lucros fictícios: formas parasitárias da acumulação contemporânea. São Paulo: Expressão Popular, 2015.

CHESNAIS, François. A mundialização do capital. São Paulo: Xamã, 1996.
DEPARTAMENTO INTERSINDICAL DE ESTATÍSTICA E ESTUDOS SOCIO-ECONOMICOS (DIEESE). Embraer reduz salários e aumenta vendas. Documento setorial, 1998.

DRUMOND, Cosme Degenar. Asas do Brasil: uma história que voa pelo mundo. São Paulo: Cultura, 2008.

EMBRAER. Projetos Kaizen e melhoria contínua. Guia de Consulta, s.d. . Relatório anual. São José dos Campos, 2000. . Relatório anual. São José dos Campos, 2001. . Relatório anual. São José dos Campos, 2003. Relatório anual. São José dos Campos, 2005. Relatório anual. São José dos Campos, 2006. Relatório anual. São José dos Campos, 2007. Relatório anual. São José dos Campos, 2008. Relatório anual. São José dos Campos, 2010. Relatório anual. São José dos Campos, 2011.

FERNANDES, Florestan. O que é revolução. In: SAMPAIO JÚNIOR, Plínio de Arruda (Org.). Clássicos sobre a revolução brasileira. São Paulo: Expressão Popular, 2005.

FERREIRA, Mariana Ribeiro Jansen. Financeirização: impacto nas prioridades de gasto do Estado - 1990 a 2007. In: MARQUES, Rosa Maria; FERREIRA, Mariana Ribeiro Jansen. (Orgs.). O Brasil sob a nova ordem - a economia brasileira contemporânea: uma análise dos governos Collor a Lula. São Paulo: Saraiva, 2010.

FONSECA, Paulus Vinícius da Rocha. Embraer: um caso de sucesso com o apoio do BNDES. Revista do BNDES,[S.1], n. 37 , jun. 2012.

FONTES, Virgínia. O Brasil e o capital-imperialismo: teoria e história. Rio de Janeiro: EPSJV/UFRJ, 2010.

GODEIRO (Org.). A Embraer é nossa! São Paulo: Sundermann, 2009.

HUSSON, Michel. Finança, hiperconcorrência e reprodução do capital. In: BRUNHOFF, Suzanne de. et al. A finança capitalista. São Paulo: Alameda, 2010.

IANNI, Octávio. A ditadura do grande capital. Rio de Janeiro: Civilização Brasileira, 1981

MALANGA, Umberto César Chacon. Análise das transformações da gestão operacional e organizacional da Embraer após a sua privatização. 1997. 96f. Trabalho de Graduação (Divisão de Engenharia de Aeronáutica) Centro Técnico Aeroespacial/Instituto Tecnológico de Aeronáutica, São José dos Campos, São Paulo, 1997.

MANDEL, Ernest. A crise do capital. São Paulo: Ensaio; Campinas: Editora da Unicamp, 1990.

MARTINEZ, Maria Regina Estevez. A globalização da indústria aeronáutica: o caso da Embraer. 2007. $340 f$. Tese (Doutorado em Relações Internacionais) - Instituto de Relações Internacionais da Universidade de Brasília, Brasília, 2007.

MÉSZÁROS, István. A crise estrutural do capital. São Paulo: Boitempo, 2009.

. Atualidade histórica da ofensiva socialista. São Paulo: Boitempo, 2010.

MIRANDA, Zil. O vôo da Embraer: a competitividade brasileira na indústria de alta tecnologia. São Paulo: Papagaio, 2007.

MORAES, Lívia de Cássia Godoi. Pulverização de capital e intensificação do trabalho: o caso da EMBRAER. 2013. 353f. Tese (Pós-graduação em Sociologia) - Instituto de Filosofia e Ciências Humanas. Universidade Estadual de 
Campinas/UNICAMP, Campinas, São Paulo, 2013.

NAKATANI, Paulo; SABADINI, Maurício de Souza. Sistema Financeiro e Mercado de Capitais. In: MARQUES, Rosa Maria; FERREIRA, Mariana Ribeiro Jansen. (Orgs.). O Brasil sob a nova ordem - a economia brasileira contemporânea: uma análise dos governos Collor a Lula. São Paulo: Saraiva, 2010.

OLIVEIRA, Kelly. O desenvolvimento da comunicação interna na Embraer, entre os períodos estatal e privado: "Quem sabe faz a hora, não espera acontecer". 2002. 121f. Monografia (Curso de Pós-Graduação em Gestão Estratégica em Comunicação Organizacional e Relações Públicas) - Escola de Comunicação e Artes. Universidade de São Paulo, São Paulo, 2002.

PAULANI, Leda. A autonomização das formas verdadeiramente sociais na teoria de Marx: comentários sobre o dinheiro no capitalismo contemporâneo. Revista Economia, Brasília , v. 12, n. 1, jan./abr. 2011.

PLIHON, Dominique. As grandes empresas fragilizadas pela finança. In: CHESNAIS, François (Org.). A finança mundializada. São Paulo: Boitempo, 2005.
. Le nouveau capitalisme. Paris: La Découverte, 2004.

PRADO, Eleutério. Exame crítico da teoria da financeirização. Crítica Marxista, [S.1], n. 39, 2014. $\begin{array}{llr}\text { REUTERS. } & \begin{array}{l}\text { Embraer } \\ \text { em: }\end{array} & \text { <http://www.reuters.com/finance/stocks/ }\end{array}$ chart?symbol=EMBR3.SA > . Acesso em: 24 dez. 2015.

SANDRONI, Paulo. Dicionário de administração e finanças. São Paulo: Record, 2008.

SILVA, Ozires. Nas asas da educação: a trajetória da EMBRAER. Rio de Janeiro: Elsevier, 2008.

TRIBUNAL DE CONTAS DA UNIÃO (TCU). Acompanhamento do processo de desestatização da EMBRAER - $2^{\mathrm{a}}$ fase. 1994. Disponível em: <http://www.tcu.gov.br/Consultas/Juris/Docs/ judoc\%5CDec\%5C19960611\%5CGERADO_TC-20615. pdf $>$. Acesso em: 26 de dez. 2015.

YOKOTA, Satoshi. A fábrica do futuro e o caso da EMBRAER. São Paulo, 2004. Disponível em: <http:// www.numa.org.br/download/Livro_F\%E1brica\%20do\%20 Futuro/apres pdf/embraer Fabr\%20Futuro-V07\%20-1. pdf $>$. Acesso em: 10 jun. $20 \overline{1} 2$. 


\section{IN THE WINGS OF THE CAPITAL: EMBRAER, financialization and implications about the workers}

\author{
Lívia de Cássia Godoi Moraes
}

The object of analysis in this article is the process of increasing financialization in the leading aeronautics company in Brazil, Brazilian Aeronautics Company S.A, (nowadays, only called EMBRAER S.A), and the impact on their direct and indirect workers. EMBRAER is the third biggest manufacturer of commercial airplanes in the world; thus, the level of competition makes the company privilege hegemonic organizational trends of global level. This investigation, centered on content analysis from official documents and scientific research published until then, verified four main moments of interconnections between productive capital and fictitious capital since its privatization in 1994, until 2012 when the research was finished. Thus, four moments come to light: 1) the 1990s, when the company was privatized; 2) in a determinant way, the beginning of the 2000's with the manufacture of commercial airplanes EMBRAER 170/190; 3) the posterior pulverization of capital in 2006; and, finally, 4) the change of the corporate name for the purpose of expanding the areas of activity of the company in 2010. The context of such changes is that of the globalization of capital and the predominance of fictitious accumulation of capital with strong impacts in the intensification of workforce use.

KEYwORDS: Financialization. Work. Restauration. Productive. Exploration.

\section{DANS LES AILES DU CAPITAL: EMBRAER, Financiarisation et implications pour les travailleurs}

Lívia de Cássia Godoi Moraes

Le sujet de cet article est le processus de financiarisation croissante dans l'entreprise leuder de l'industrie d'aviation brésilienne, EMBRAER - Entreprise Brésilienne d'Aéronautique S.A, aujourd'hui, seulement EMBRAER S.A -, et ses concéquences sur le travail et ses travailleurs directs et indirects. L'EMBRAER est la troisième plus grande productrice d'avions commerciaux du monde, dont le niveau de la concurrence l'induit a donner la priorité à des tendances organisationnelles hégémoniques dans le contexte mondial. La recherche, concentrée sur l'analyse de contenu, à partir des documents officiels et des recherches scientifiques jusqu'à ce moment publiées, a identifié quatre principaux moments de forte chevauchement entre capital fictif et capital productif depuis sa privatisation, en 1994, jusqu'à l'année de 2012, quand quand la recherche se ferme: 1) à partir de 1994, quand l'entreprise a été privatisé ; 2) De façon déterminante, dans le début des années 2000, avec la production des avions commerciaux de la famille EMBRAER 170/190 ; 3) avec la subséquent pulvérisation des capitaux, en 2006; et, enfin, 4) aprés le changement de la dénomination sociale dont l'objectif était élargir les zones d'opération de l'entreprise, en 2010. Le contexte dans lequel ces changements se produisent est la mondialisation du capital avec la prévalence de l'accumulation de capital fictif , qui a des forts impacts sur l'utilisation intensifiée de la main-d'œuvre.

EMBRAER. Mots-CLÉS: Financiarisation. Travail. EMBRAER. Restructuration Productive. Exploration.

Lívia de Cássia Godoi Moraes - Doutora em Sociologia. Professora do Departamento de Ciências
Sociais e do Programa de Pós-Graduação em Política Social da Universidade Federal do Espírito
Santo. Coordenadora do Programa Institucional de Bolsas de Iniciação à Docência (Pibid), subprojeto
de Ciências Sociais. Desenvolve pesquisas na área de Sociologia do Trabalho, Educação e Economia
Política. Publicações recentes: Imbricações entre terceirização e financeirização no Brasil: um debate
acerca do Projeto de Lei da Terceirização" (livro de Edvânia Lourenço (Org.); Saúde do trabalhador e
da trabalhadora e Serviço Social, pela editora Papel Social, 2016); O tripé vilipendiador do trabalho:
reestruturação produtiva, neoliberalismo e financeirização" (livro de Vera Navarro e Edvânia Lourenço
(Orgs); O avesso do trabalho IV, pela editora Outras Expressões, 2017, em co-autoria com Caio Antunes,
Hugo Silva e Joana Freitas. 
